\title{
More and Better Saving for Productive Investment
}

Why save more? One good reason is to invest more. Economies that save more can take advantage of investment opportunities and thus grow faster. Investing to improve access to education and health, for example, can boost growth by increasing people's productivity and income. Investing in plants and machinery is critical to maintain, expand, and incorporate technological progress in countries' productive structures.

Among all investment types, investment in infrastructure is one of the most crucial for growth. Infrastructure (transport, telecommunications, energy, and water and sanitation) complements other forms of capital and labor. If properly planned and built, it can eliminate bottlenecks that reduce growth potential. What differentiates infrastructure from other forms of capital is the need for long-term financing to pay for it. This financing should be in local currency as much as possible, which is precisely the type of financing that national saving provides. The challenge going forward for Latin America and the Caribbean is how to develop the proper instruments to channel national saving to infrastructure. This chapter also explores the region's options to enhance infrastructure as an asset class and make it an attractive investment opportunity for institutional investors.

\section{Investment and National Saving: Low, Lower, Lowest}

Investment has the potential to impact growth positively in both the short and long term. In the short to medium term, investment generates growth by boosting aggregate demand. In the long term, investment's growth effect works via aggregate supply and the productive apparatus; 


\section{BOX 4.1. DEFINITION OF GROSS FIXED CAPITAL FORMATION}

The variable used in national accounts to measure investment is Gross Fixed Capital Formation (GFCF). GFCF is a component of a country's gross domestic product (GDP), together with consumption, government spending, and net exports. It includes land improvements (fences, ditches, drains); plant machinery and equipment purchases; and the construction of roads, railways, and other infrastructure. It also includes schools, offices, hospitals, private residential dwellings, and commercial and industrial buildings. ${ }^{a}$

a The precise definition of Gross Fixed Capital Formation is provided in the World Bank's World Development Indicators (2015b).

higher investment triggers technological changes, induces higher productive capacity, and fosters resource reallocation toward higher productivity sectors (Jiménez and Manuelito, 2013).

If investment is such an important determinant of economic growth, then it's crucial to ask whether Latin America and the Caribbean is investing enough. If comparisons with other regions are any indication, the answer is no. Latin America and the Caribbean has systematically invested less over time than other regions.

When countries are grouped by income level, the evolution of investment follows two distinct paths (Figure 4.1). Up to 2000, lowand-middle and high-income countries invested a similar share of GDP, around 23 percent. ${ }^{1}$

Figure 4.11 Private Investment in Infrastructure, 1990-2012

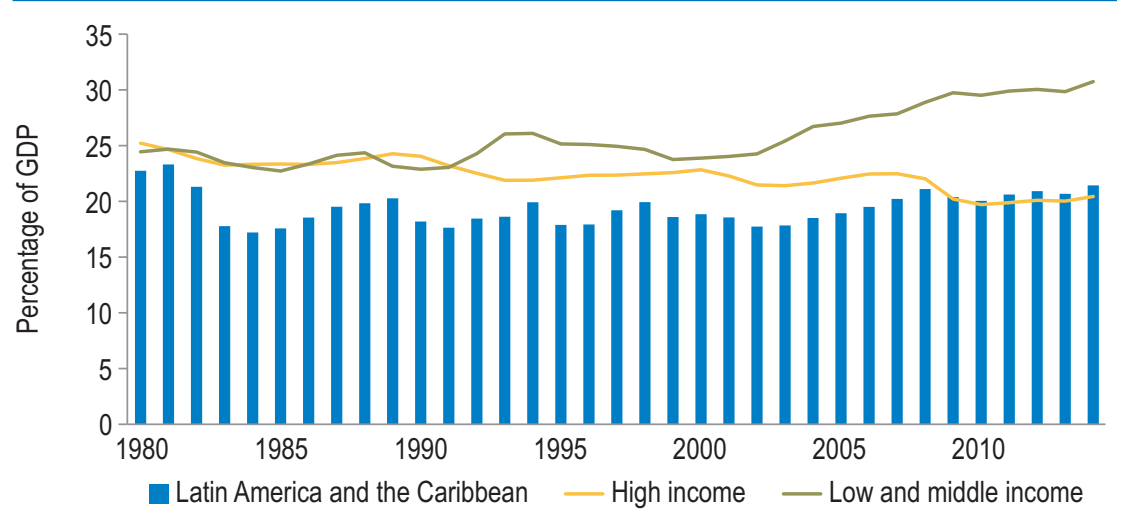

Source: Authors' calculations based on Serebrisky, Margot, and others (2015). 
However, after 2000, low-and-middle-income countries began to invest an increasing share of GDP, while gross fixed capital formation (GFCF) among high-income countries began to decline. Since most countries in Latin America and the Caribbean are low-and-middle-income countries, the region should follow the pattern of increasing investment. Instead, average GFCF in the region between 2000 and 2014 was 20 percent-much lower than the 25 percent average for lowand-middle-income countries in the same period.

Apparently, 25 percent is a sort of magic number when it comes to investment. According to the Commission on Growth and Development, 25 percent is the minimum investment level compatible with long-term growth. ${ }^{2}$ Its 2008 report on growth analyzed 13 economies ${ }^{3}$ that grew an average 7 percent a year or more for at least 25 years between 1950 and 2005. The diverse sample of countries included economies on four continents, big and small countries, some rich in natural resources, and others that were not. All 13 success stories experienced investment rates above 25 percent of GDP during the periods of high growth-hence the conclusion that a 25 percent of GDP investment rate is the minimum necessary level compatible with sustained economic growth.

Unfortunately, Latin America is far from the 25 percent benchmark recommended by the Commission. With the exception of Haiti, which only reached the threshold thanks to extensive external assistance, no other country in Latin America and the Caribbean has come close to the 25 percent benchmark (Figure 4.2). The regional average between 1980 and 2014 was just 20 percent.

Investment in Latin America is not only low; a breakdown of investment by region confirms that between 1980 and 2014, Latin America and the Caribbean had the lowest GFCF flows of any region (Figure 4.3). The comparison with Emerging Asia is the most striking, with an investment gap equivalent to 10 percent of Latin America's annual GDP between 1980 and 2013. Sub-Saharan Africa invested 1.7 percent of GDP more than Latin America and the Caribbean during the period.

While Latin America and the Caribbean has recorded low GFCF in recent decades, it has enjoyed a few episodes of high GFCF. A review of 770 country-year observations in 25 countries in the region between 1980 and 2013 identified 70 cases of high investment (defined to be higher than the threshold 25 percent of GDP), or 9 percent of the observations. Thus, Latin American and Caribbean countries can achieve high levels of investment, even in a context of low averages. These cases, 
Figure 4.2 Average Investment, National Saving, and Foreign Saving Rates, 1980-2014

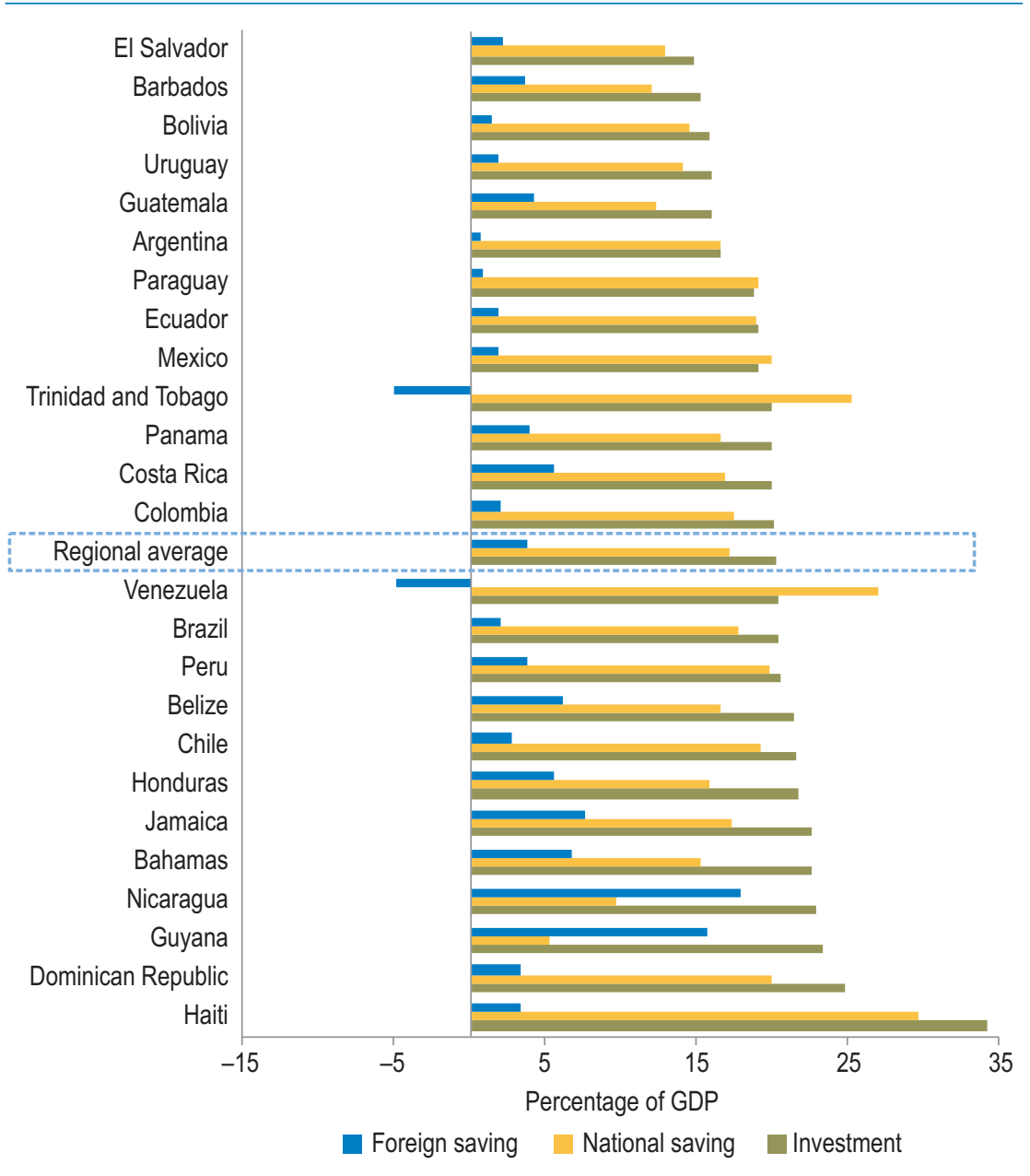

Source: Authors' calculations based on World Economic Outlook database (IMF, 2015).

however, are concentrated in a few countries (most of them in the Bahamas, Honduras, Jamaica, and Trinidad and Tobago) scattered across different years and likely related to reconstruction after natural disasters. The challenge for the region is to extend these successful experiences to more countries and sustain high investment rates for consecutive years.

Investment in Latin America and the Caribbean is not only relatively lower than in other regions, it is also more volatile. While volatility patterns vary by country, they generally consist of scattered investment 
Figure 4.3 Gross Fixed Capital Formation by Region, 1980-2014

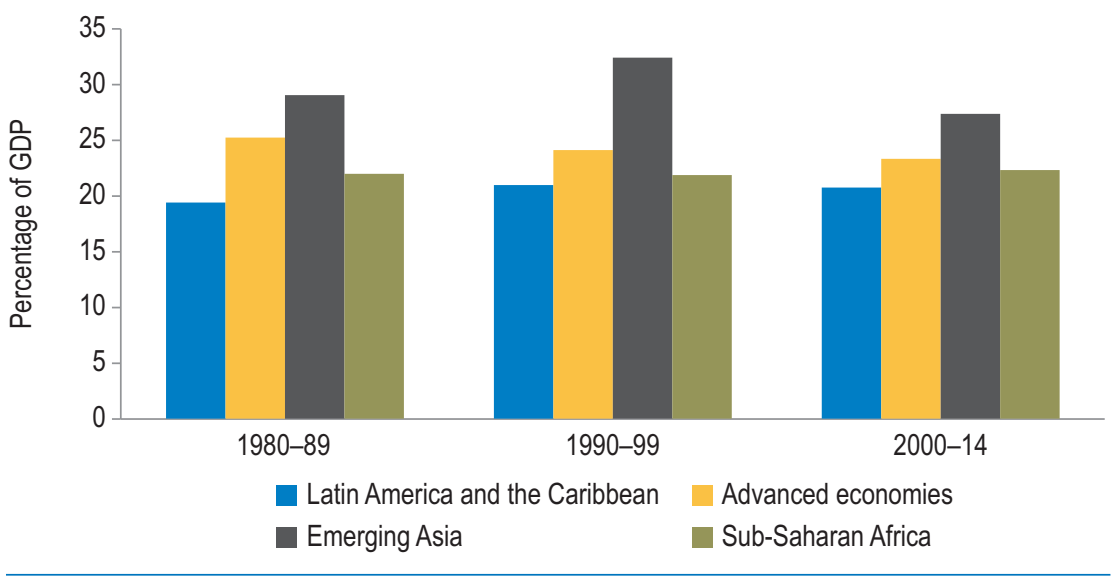

Source: Authors' calculations based on World Economic Outlook database (IMF, 2015).

peaks followed by years of low investment rates. Using the coefficient of variation (the ratio between the standard deviation and the mean of series) to measure volatility, China, the advanced economies, and Emerging Asia (excluding China) have the lowest volatility. ${ }^{4}$ Interestingly, the countries with the most stable series of investment (China and the rest of Emerging Asia) also have the highest levels of investment, while SubSaharan Africa-the most volatile region-along with Latin America and the Caribbean, are the regions that invest the least.

So who is to blame for this low level of investment in Latin America and the Caribbean? Is it the public sector, the private sector, or a more systemic problem of the economic environment that leads to low levels of investment by both the public and private sectors? Unfortunately for Latin America and the Caribbean, the answer is that both public and private investment are low compared to other regions and country groupings (Figure 4.4).

While private investment is the main component of total investment in Latin America and the Caribbean, as it is in all regions, private investment in Latin America and the Caribbean is lower than in the rest of the world; the only exception is Sub-Saharan Africa. Public investment is also low by international standards. Given that the difference has persisted over time, Latin America and the Caribbean is opening an investment gap with the world. What is worrisome is that this gap has been present since the 1980 s and there are no signs of it getting any smaller. 
Figure 4.4 Average Gross Fixed Capital Formation by Region, 2000-2014

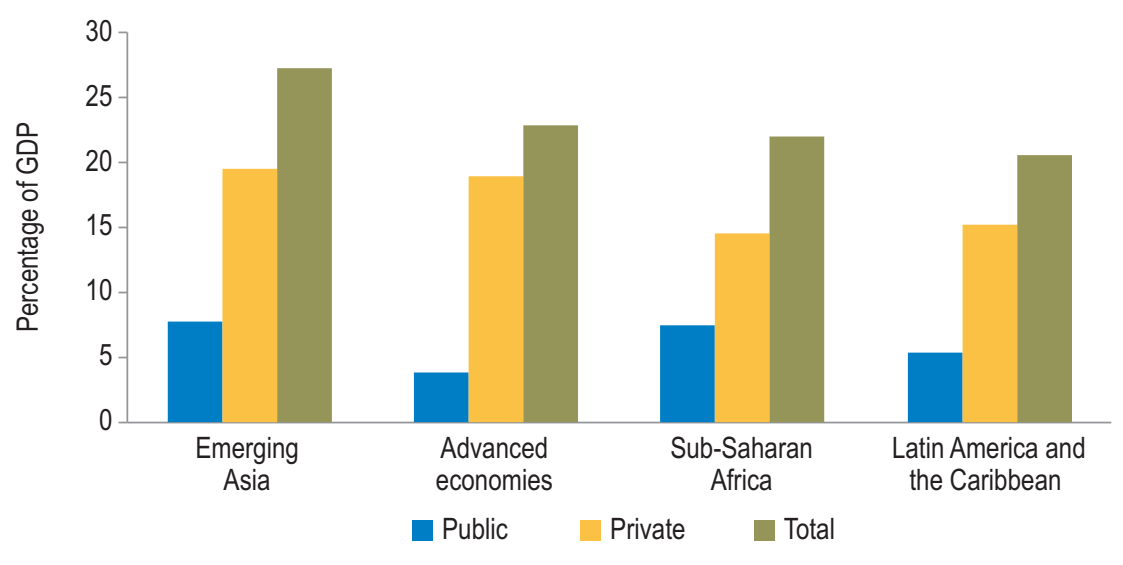

Source: Authors' calculations based on IMF (2015).

\section{Financing Investment: No Place Like Home}

National and foreign saving are the only options economies have to finance investment. A quick glance at the evolution of investment and national saving in Latin America and the Caribbean shows that as low as investment has been, it has still been higher than national saving since 1980, with the exception of only one year (Figure 4.5). The experience of other regions is very different. Indeed, national saving is higher than investment in the economies that invest the most: Emerging Asia. ${ }^{5}$ In contrast, Latin America and the Caribbean has relied on foreign saving to finance its investment. On average, the region had to "import" saving in amounts equivalent to 3.5 percent of GDP.

Without increasing national saving, Latin American and Caribbean countries would need to boost foreign saving from the current 3.5 percent of GDP to 8 percent to catch up with the critical 25 percent of GDP investment level needed for growth rates above 5 percent. That's double the current foreign saving rates! Even economies with access to foreign financing would find it difficult to finance a gap between the domestic investment and national saving rates much above 5 percent of GDP (Corbo, 1998). Data confirm this hypothesis for almost every country in Latin America and the Caribbean: with the exception of Nicaragua and Guyana, no country in the region was capable of sustaining foreign saving rates above 8 percent of GDP for prolonged periods of time. ${ }^{6}$ 
Figure 4.5 National Saving and Investment in Latin America and the Caribbean and Emerging Asia, 1980-2014

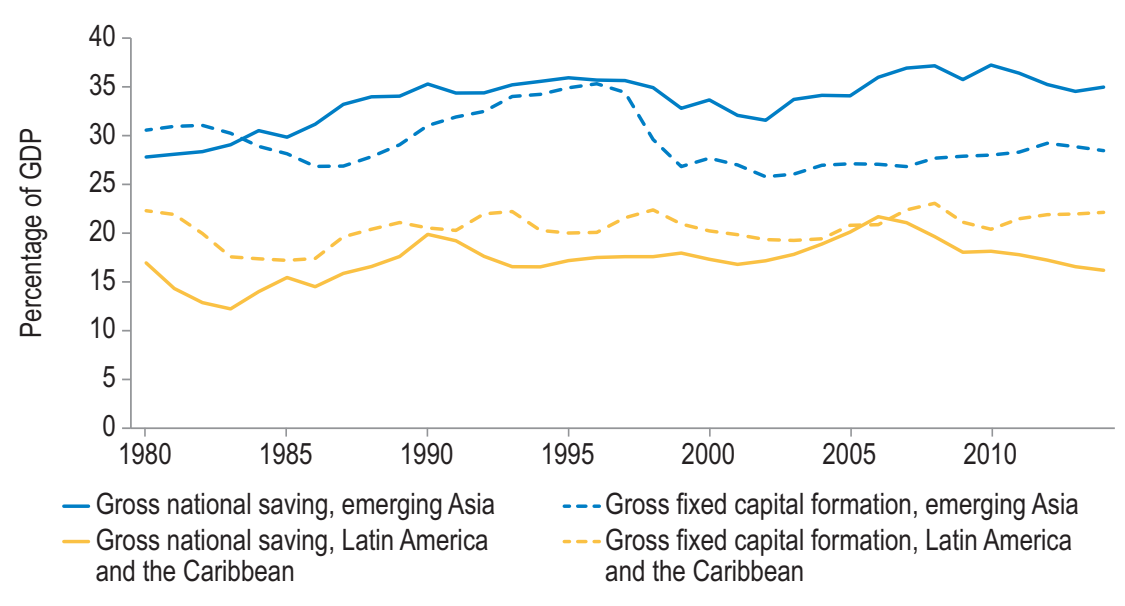

Source: Authors' calculations based on World Economic Outlook database (IMF, 2015).

A dramatic increase in foreign saving, while possible, might not be desirable. Relying on foreign saving to finance domestic investment is risky, for various reasons. In the first place, national transaction costs that affect expected returns, perceived riskiness of assets in foreign currencies, and information asymmetries induce home bias in investing. Local investors tend to invest in local assets (either in national firms or foreign firms with local presence) much more than they invest in foreign markets (Coeurdacier and Rey, 2013; Ke, Ng, and Wang, 2010). Second, foreign capital flows tend to be volatile and prone to sudden stops (Calvo, Izquierdo, and Loo-Kung, 2006), so relying less on foreign saving reduces vulnerability to crises provoked by turbulent international financial markets. Moreover, it is difficult to maintain large current account deficits (of the magnitude required to close the investment gap with foreign saving alone) for prolonged periods of time without abrupt reversals, or external indebtedness problems (Powell, 2013). ${ }^{7}$

In a fully integrated world economy, the origin of saving is irrelevant, as profitable domestic investment opportunities would find financing, either locally or from the rest of the world. In this ideal world, national saving need not correlate strongly with domestic investment. But can the data confirm the decoupling of investment and the source of saving? A paper by Feldstein and Horioka (1980) finds otherwise. For a sample of 16 member-countries of the Organisation for Economic Co-operation 
and Development (OECD) from 1960 to 1974, increases in national saving were matched by practically equal increases in domestic investment. ${ }^{8}$ Feldstein and Horioka (1980) conclude that international capital is not perfectly mobile; hence, an economy in need of increasing investment must rely on additional domestic capital (saving) to finance it. Research on Latin America and the Caribbean confirms the close link between investment and national saving. In the period 1980-2012, for every 1 percentage point increase in national saving, domestic investment increased by almost 0.4 percentage points (Cavallo and Pedemonte, 2015).

While Feldstein and Horioka's study is centered on flows-domestic investment rates and national and foreign saving rates-the same results hold when examining stocks-domestic capital stock and the stock of national savings. In developing countries, more than 90 percent of the stock of capital is self-financed-which means that foreign savings have not provided a materially sufficient source for financing domestic capital. This result was obtained by calculating self-financing ratios (SFR): the stock of tangible capital financed by past national saving, relative to the actual stock of capital (Aizenman, Pinto, and Radziwill, 2007). Aizenman, Pinto, and Radziwill define the SFR as the ratio of discounted past national saving and discounted past domestic investment. Intuitively, the self-financing ratios capture the proportion of the current domestic capital stock that is financed with past local savings. An SFR of 1 would correspond to an economy in which the entire stock of domestic capital is self-financed. A self-financing ratio below 1 indicates reliance on foreign saving. An SFR above 1 describes an economy that is a net exporter of capital, and contributes to finance capital in the rest of the world.

Recent SFR calculations for 1980 to 2011 using data from the International Monetary Fund's World Economic Outlook (WEO) database show that, as of 2011, while SFR are above 80 percent in all regions of the world, in Latin America and the Caribbean, they are 96 percent, a value that confirms the results of Aizenman, Pinto, and Radziwill (2007). As expected, Asian economies have the highest ratios, surpassing 1 (Figure 4.6). Overall, for advanced economies and all other country groupings, the SFR are very close to $1,{ }^{9}$ indicating that most domestic capital stock is supported by past national saving. Importantly, SFR are growing in all regions, and especially in developing regions. Between 1980 and 2010, Latin American and Caribbean countries increased their SFR from 81 percent to 96 percent, Sub-Saharan African countries raised theirs from 69 percent to 79 percent, and the region that invests the 
Figure 4.6 Self-Financing Ratios by Region, 1980-2011

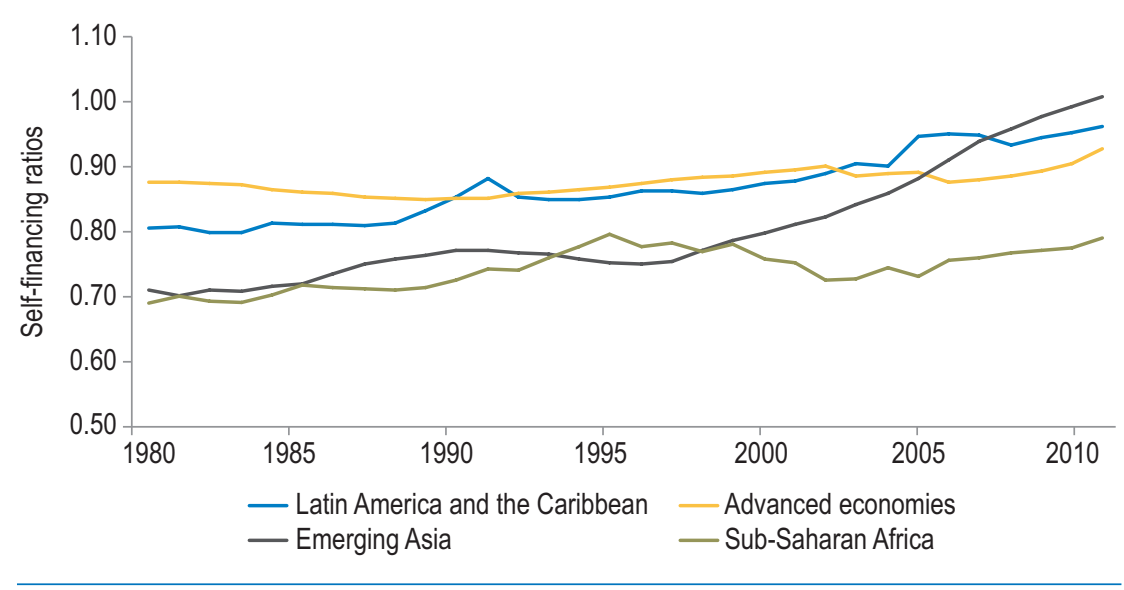

Source: Authors' calculations based on data for years 1960-2011 from World Development Indicators database, based on methodology from Aizenman, Pinto and Radziwill (2007), extended on Cavallo, Fernández-Arias, and Marzani (2016).

most, Emerging Asia, also increased its SFR the most: from 71 percent to 106 percent. These trends confirm that countries rely mostly on national saving to finance domestic capital stocks. The message is clear: there's no place like home as a source of saving for investment.

\section{For Policy, Which Comes First: Saving or Investment?}

The existence of a high positive correlation between national saving rates and domestic investment rates is one of the most robust and stable regularities observed in the data across countries and decades (Baxter and Crucini,1993). However, correlation does not mean causation. Does national saving drive investment, or vice versa? Is investment in Latin America and the Caribbean low because of the lack of national saving, or is national saving low because of low investment rates? There are arguments that support both points of view (see Serebrisky, Margot, et al., 2015).

Chapter 10 describes how episodes of important increases in total factor productivity generate expectations of higher returns on investment and thus incentivize subsequent increases in savings to take advantage of the enhanced return opportunities. This argument suggests that in an economy, saving increases endogenously when better investment opportunities exist. However, even if such a favorable environment 
sparks a sharp increase in investment demand, for that investment to materialize, the domestic saving rate must also rise. In this context, policies that mobilize saving will help bring about higher investment rates in the economy (Corbo, 1998).

The argument in Chapter 10 does not invalidate the exogenous components of saving and the evidence that increases in saving tend to precede higher levels of investment. Empirical evidence for the world and for Latin America and the Caribbean shows that national saving precedes investment, but investment does not anticipate future saving. ${ }^{10} \mathrm{~A}$ 10 percent increase in past national saving raises current investment by 1 percent, while an increase in past investment has no significant effect on current saving. This is true regardless of indirect channels through which investment and saving could affect each other. For example, current investment might generate growth, which in turn increases future savings. The data show that saving drives investment even considering the indirect effect through growth, but the reverse is not true. However, there are episodes (particular countries, or certain years) in which causality runs in both directions. For example, in LAC-7 (Argentina, Brazil, Chile, Colombia, Mexico, Peru, and Venezuela), past saving increases current investment and past investment drives current saving (Serebrisky, Margot, et al., 2015).

Bidirectional effects do not invalidate the main premise: national saving in Latin America and the Caribbean must increase if the region is to foster investment. However, higher saving is only a necessary condition to increase investment, not a sufficient one: in some recent examples in Latin America and the Caribbean, investment did not catch up with significant increments in national saving."

Moving forward, the most important policy recommendation is that policies to promote national saving and policies to promote investment should be consistent (Cavallo and Pedemonte, 2015). If pro-savings policies unintentionally discourage investment, then those policies will likely fail. This is not merely an abstract debate; some popular pro-savings policies, such as tax breaks to encourage local saving, have backfired. For example, in 1989, Mexico lowered the tax rate for distributed dividends to facilitate the flow of profits from companies to shareholders, which could then be channeled toward investments in other firms. However, this reform was implemented at a time when the relative prices of consumption goods and real estate were distorted. Thus, shareholders channeled the additional income to purchase consumer goods and 
real estate rather than toward financing investments in other firms. Corporate saving diminished because the lower retained earnings and household saving did not cover the difference. As a result, private saving declined from 12 percent of GDP in 1989 to an average of 8 percent for the period 1991-93 (see Calderón-Madrid, 1998).

\section{Investment in Infrastructure: First among Equals?}

Why is it important to analyze investment in infrastructure in a book about saving? Among investment alternatives, infrastructure is unique: it has characteristics of a public good, and the role of the public sector is vital to make it as productive as possible; it requires long-term financing; Latin America and the Caribbean invests too little and does not always allocate funding to the best infrastructure projects; and the region has proven incapable of channeling a significant share of private savings to infrastructure. No other component of investment more accurately reflects Latin America and the Caribbean's dual need to save more and to save better. The region must save more to increase investment in infrastructure and save better, channeling more savings to an asset class that is highly productive.

\section{A Catalyst for Productivity and Growth}

Infrastructure encompasses transport, energy, water and sanitation, and telecommunication assets. It is a component of the capital stock of a country and serves as an enabler to the supply and demand of services or, more technically, as an input in the production function. It is virtually impossible to think of the production process in modern societies or the demand for basic services such as education or health without the existence of reliable roads, water, and electricity services. Thus, infrastructure impacts growth by improving productivity, reducing production costs, facilitating human capital accumulation by easing access to educational facilities, helping diversify the productive structure, and creating employment through demand for the goods and services used to provide it.

Recent empirical research shows a positive correlation between growth and infrastructure investment in Latin America. Calderón and Servén (2010) find that comparing 1991-95 and 2001-05, the accumulation of infrastructure stock contributed 1.1 annual percentage points to 
economic growth in this region. Standard \& Poor's (2015) find that three years after an increase in infrastructure investment of 1 percent of GDP, the GDP of Brazil would jump 2.5 percent, Argentina 1.8 percent and Mexico 1.3 percent. ${ }^{12}$

How much infrastructure investment does Latin America and the Caribbean need? This is probably the most frequently asked question in the infrastructure public policy arena in the region. Clearly motivated by the plummeting volumes of infrastructure investment since the late 1980s (Figure 4.7), this question has inspired several academic and policy publications to try to quantify the region's infrastructure gap (Calderón and Servén 2003; Kohli and Basil, 2011; Perrotti and Sánchez, 2011).

The most common ways of measuring an infrastructure gap include determining the infrastructure a country or region needs to meet a target growth rate, to achieve a specific objective such as a coverage rate (for example, 100 percent access to water and sanitation), or to achieve an infrastructure stock similar to a country or group of countries. Regardless of the definition of the gap and the methodologies used, the results are the same: Latin America and the Caribbean needs to invest at least 5 percent of GDP in infrastructure for a prolonged period of time. Assuming the estimates are right, the region requires additional investment in infrastructure in the range of 2 to 2.5 percent of GDP per year, or the equivalent of US $\$ 120$ billion to US $\$ 150$ billion (based on the region's GDP in 2013).

\section{Figure 4.7 Evolution of Infrastructure Investment, 1980-2013}

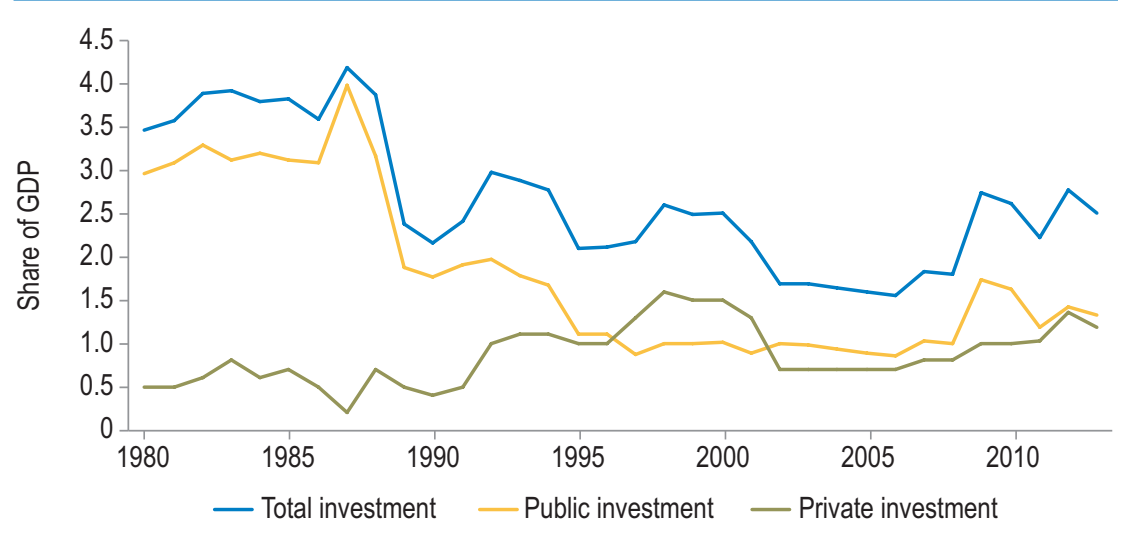

Source: Authors' calculations based on Calderón and Servén (2010), CAF (2013), and ECLAC (2014a). Note: The figure includes data for Brazil, Chile, Colombia, Mexico, and Peru, the countries for which data from the 1980 s are available. 
Investment in infrastructure in the region averaged 2.4 percent of GDP from 1992 to 2013, while investment in other regions and countries was significantly higher during the same period: 8.5 percent in China, 5 percent in Japan and India, and around 4 percent in other industrialized countries. ${ }^{13}$ Moreover, Latin America and the Caribbean's infrastructure investment is 0.8 percent of GDP lower than in the United States and the European Union, regions with a much more developed capital stock that require relatively more maintenance investment than new infrastructure capacity (McKinsey Global Institute, 2013).

Investment in infrastructure is low across Latin America and the Caribbean and has taken its toll on the quality of the region's infrastructure services. Only one small country (Nicaragua) surpassed the 5 percent of GDP threshold between 2008 and 2013. None of the largest economies (Argentina, Brazil, Chile, or Mexico) invested more than 3 percent of GDP-much less than what is needed to close the infrastructure gap (Figure 4.8). The World Economic Forum's survey of infrastructure quality perceptions-the most cited and used worldwide- is conclusive:

Figure 4.8 Investment in Infrastructure by Country 2008-13 (annual average)

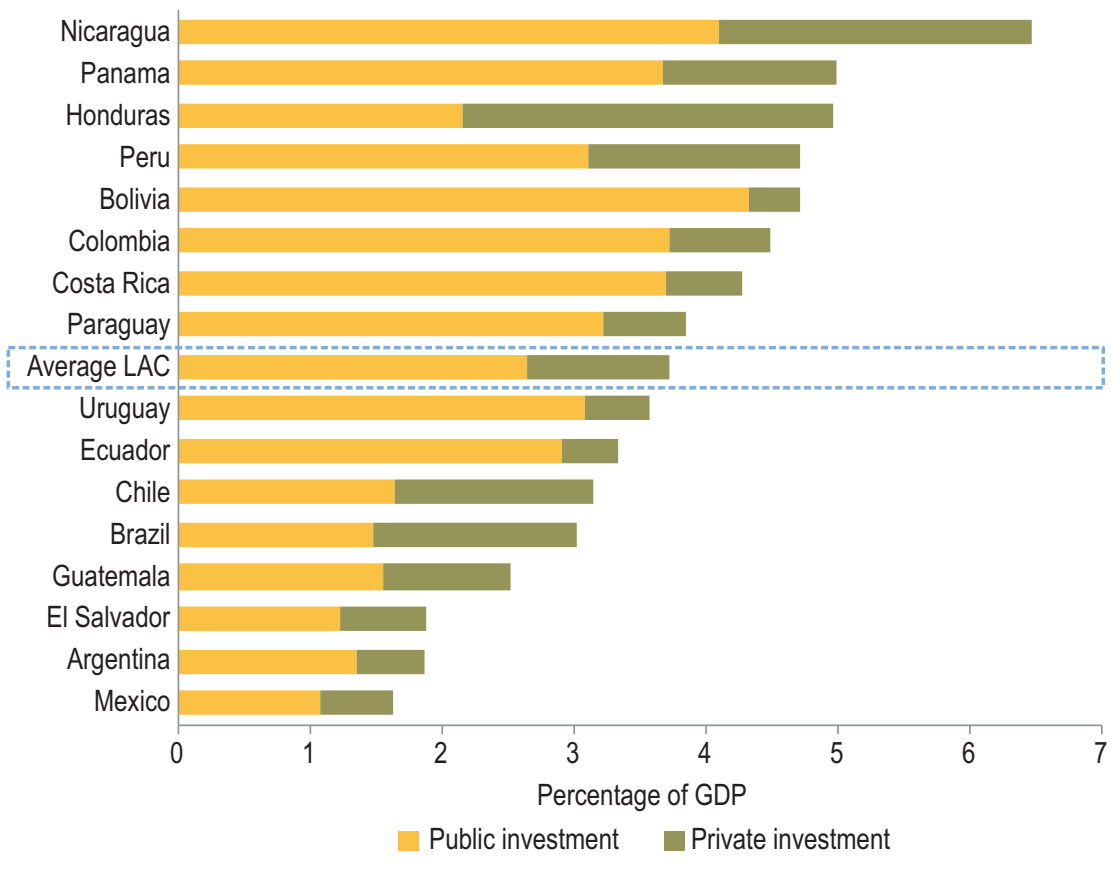

Source: Authors' calculations based on CAF (2013) and ECLAC (2014a). 
the quality of infrastructure in Latin America and the Caribbean is lagging behind, particularly when compared with advanced economies and Emerging Asia. Even more worrisome is the comparison with SubSaharan Africa, which is reducing its quality gap. In Latin America and the Caribbean, quality increased slightly between 2006 and 2014, but Sub-Saharan Africa improved much more. If the trend continues, Latin America and the Caribbean will be the region with the lowest perception of infrastructure quality. ${ }^{14}$

\section{Public or Private Investment: Both Is Best}

Infrastructure requires rigorous planning because it creates both positive externalities (network effects), as well as negative ones (mainly in the environmental and social realms). It also requires proper supervision to make sure services comply with adequate quality standards. These activities must be performed by the public sector. However, the public sector need not provide infrastructure services directly. In many countries, infrastructure services are provided by private firms through a variety of arrangements, such as management contracts or concessions, that commonly fall under the umbrella term "public-private partnerships" (although the specific arrangements have different legal and economic connotations in Latin American and Caribbean countries).

\section{Figure 4.9 Perceived Infrastructure Quality: A Regional Comparison, 2006-15}

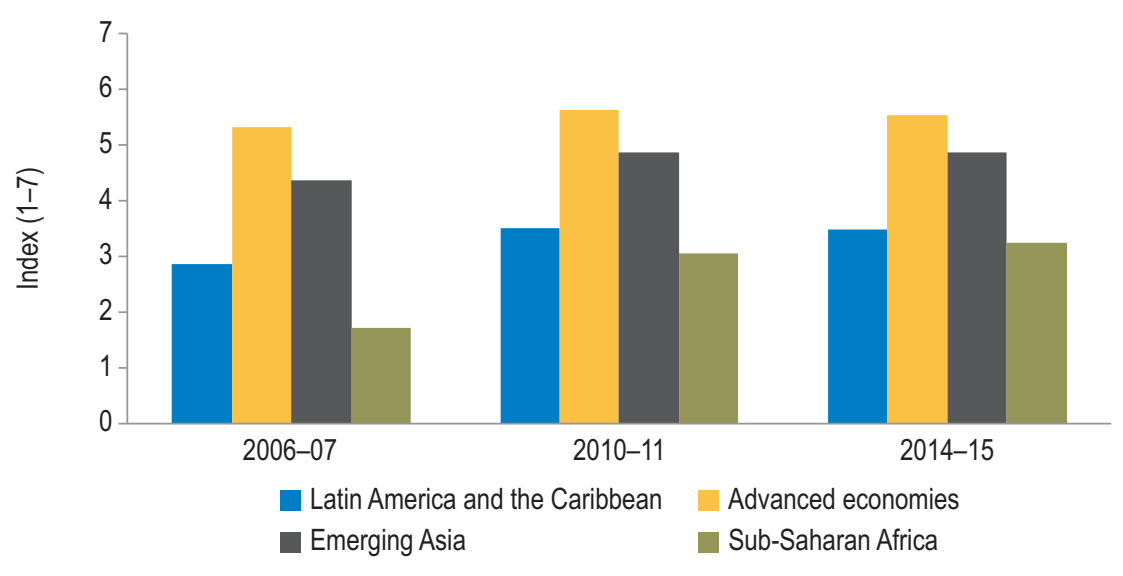

Source: Authors' calculations, based on World Economic Forum (2006, 2010, 2014). Note: The perception index is based on a scale from 1 (worst) to seven (best). 
Despite falling from its 1980 s peak (see Figure 4.7), public investment in infrastructure is higher than private investment in all countries in Latin America and the Caribbean. The decline in public investment was the consequence of two factors: less fiscal space following the macroeconomic adjustment policies in the 1990s that reduced public spending, and a concurrent belief that opening infrastructure services to private ownership and operations would compensate for lower public investment in infrastructure (Fay and Morrison 2007). Unfortunately, the role of private investment in infrastructure has increased, but not enough to replace public investment.

From 1990 to 2013, the region accumulated US $\$ 680$ billion in private investment, exceeding Emerging Asia (US\$503 billion) and Sub-Saharan Africa (US\$130 billion). Even though the level of private investment increased from the early 1990s, reaching 1.5 percent of GDP in some years, it never achieved expected levels, leaving the region with much lower total investment levels as a percent of GDP than in the 1980s.

Undoubtedly, Latin America and the Caribbean needs more investment in infrastructure and, given the size of the infrastructure gap, both public and private investment will have to increase. But is there room to increase both public and private investment? The answer is a qualified yes, if actions and policies specific to each sector are adopted.

Public investment in infrastructure, expressed as a percentage of total public investment, fell during the 1990s and remained at 30 percent until the mid-2000s. Starting in 2005, the composition of public investment changed, and the share devoted to infrastructure rose from 30 percent to 50 percent. Public investment in infrastructure as a share of total public expenditure increased as well from 2005 onward, but only managed to reach the level of the 1990s (Figure 4.10). ${ }^{15}$ The challenge for Latin America and the Caribbean is to sustain the increase in public infrastructure investment. Unfortunately, if history is any guide, prospects are not favorable to ramp up infrastructure investment permanently.

When fiscal conditions deteriorate, infrastructure investment is among the main budgetary items to be axed. In times of crisis or recession, cuts in public capital expenditures-particularly infrastructure investment-are proportionally much higher than cuts in current expenditures or new tax revenue. ${ }^{16}$ Carranza, Daude, and Melguizo (2014) argue that between 1987 and 1992-a period of financial and fiscal crises in Latin America and the Caribbean-one-third of the improvement in fiscal accounts came at the expense of lower infrastructure investment: 
Figure 4.10 Public Investment in Infrastructure, 1990-2012

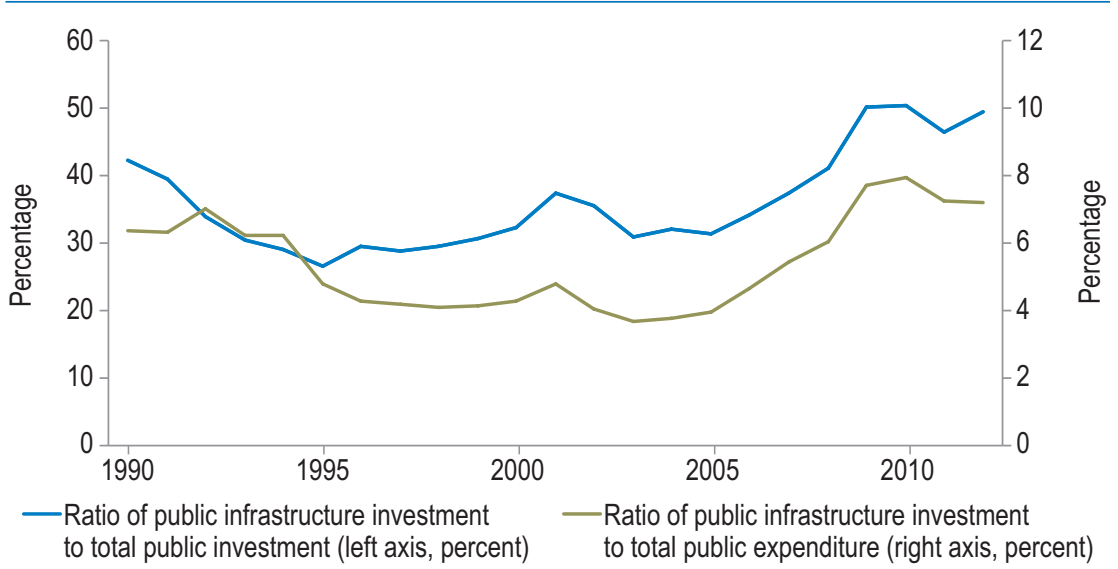

Source: Authors' calculations based on Serebrisky, Margot, and others (2015).

public deficits shrank by 6 percent of GDP, and public investment in infrastructure diminished, on average, by 2 percent of GDP-equivalent to reducing public infrastructure investment by more than 60 percent. Evidence for the first half of 2015 for subnational governments in Brazil indicates that the slowdown in economic growth forced states to reduce their investment in infrastructure by 46 percent. ${ }^{17}$

What can be done to increase public investment in infrastructure on a sustainable basis and thus help close the infrastructure gap? Unavoidably, public saving must increase. But how can it increase? One option is to create more fiscal space through additional revenues (such as general tax financing) and channel it to infrastructure. Another option is to change the composition of public expenditure, reducing current expenditures in favor of capital (infrastructure) investment. Other necessary policies include i) increasing user fees in sectors where tariffs are lower than cost recovery levels; ii) implementing charges to capture value that results from new infrastructure; and iii) boosting the efficiency of public investment in infrastructure by streamlining the project cycle of infrastructure delivery from planning to procurement, better supervising works, and raising the quality of regulation of infrastructure services.

The key policy message is that to increase public investment in infrastructure, public saving needs to increase. Public saving does not need to come via additional taxation or budget cuts. Switching from current 
to capital expenditures and improving expenditure efficiency can boost public saving and generate additional resources for public investment (see Chapter 8).

\section{The Other Half}

The public sector cannot do it alone. The way forward for the region is to generate the conditions required to substantially increase private investment in infrastructure. How much does private investment need to increase? The answer depends on the future behavior of public investment. Assuming, just as an exercise, it reaches an optimistic level of 2 percent of GDP, private investment would need to triple (from 1 percent to 3 percent of GDP) to reach the threshold of 5 percent of GDP required to close the infrastructure gap. Just by looking at the evolution of private investment in infrastructure compared with total private investment and national private saving (Figure 4.11), it is clear that private investment in infrastructure has room to grow-at least to match the values observed in the late 1990s.

Boosting private investment in infrastructure requires simultaneous action on two fronts: strengthening regulatory and institutional capacity to generate a well prepared pipeline of projects; and developing infrastructure as an asset class to channel private savings to

Figure 4.11 Private Investment in Infrastructure, 1990-2012

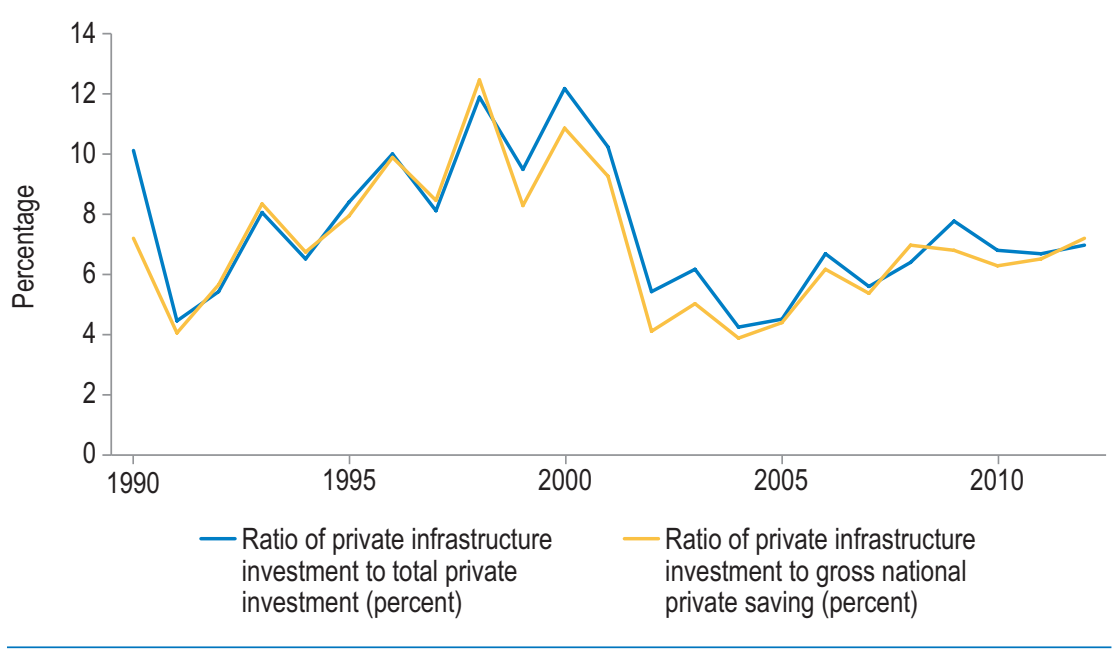

Source: Authors' calculations based on Serebrisky, Margot, and others (2015). 
infrastructure. An important body of knowledge addresses the specifics of how to design and implement projects with private participation or public-private partnerships. ${ }^{18}$ The available studies concentrate almost exclusively at the project level, focusing on the project's characteristics (sector, investment commitments, sponsors, finance structuring) and its performance (productivity, quality of services). However, there is a notable lack of evidence on what the region must do to promote infrastructure as an asset class. Surprisingly, there is no regional macro-level analysis of the financing sources used to pay for infrastructure. That is, regardless of who builds and operates the assets, the question of where the financing comes from (whether national or foreign savings) remains unanswered.

The following sections analyze the private infrastructure financing market in Latin America and the Caribbean in depth and lay out an agenda to make infrastructure a more appealing asset, particularly to institutional investors, which administer an increasing amount of private savings.

\section{Understanding the Infrastructure Financing Market}

Infrastructure assets are different from all other assets (industrial buildings, machinery equipment, schools) that make up the definition of Gross Fixed Capital Formation. They involve significant upfront construction costs, imply high initial risks due to unexpected construction costs followed by uncertain demand, generate revenues only after the largest expenditure (construction costs) has been made, and cannot be reconverted to alternative uses. Given these particular characteristics, the only feasible way to pay for most infrastructure assets is with longterm financing.

Foreign saving to finance infrastructure is possible, but not likely in the region. Even in recent years, with positive growth prospects and foreign direct investment (FDI) reaching 3 percent of GDP, only 10 percent of that amount has gone to infrastructure, and almost all of that has been concentrated in Chile and Brazil (Powell, 2013). Given this history of FDI flows to infrastructure, foreign saving is clearly not a game changer for infrastructure financing in Latin America and the Caribbean.

But volume isn't the only problem with FDI. Local currency provides other clear advantages as a source of long-term financing. In Latin 
America and the Caribbean, where capital markets are not sufficiently developed, hedging opportunities are not usually available; thus external financing is difficult to secure for infrastructure projects, whose assets have no alternative use. In addition, there is a mismatch between the income, in local currency, obtained from infrastructure and the payment of debt obligations in external currency. This currency mismatch has been a source of instability and renegotiation of long-term contracts for infrastructure services. Another reason why long-term financing in local currency should be available is that international investors usually require the active participation of local investors as co-financiers in infrastructure projects. All evidence suggests that national saving in sufficient quantity and good quality (channeled with the appropriate instruments to accommodate the specific needs of infrastructure) will be necessary to close the prevailing infrastructure gap in Latin America and the Caribbean.

A rash of policy reports by multilateral development banks, the Group of Twenty (G-20), think tanks, and academics, sparked by the decline in available financing for infrastructure and budget cuts in several countries following the financial crises of 2008-09, came to an additional conclusion: greater private sector participation in infrastructure is the only way to maintain and improve the stock and quality of infrastructure services. ${ }^{19}$ The reports shared another worrisome finding: there is an alarming lack of information about who is included in the definition of private sector, what the role of each private sector actor is, and which vehicles they prefer for channeling infrastructure investments. Not surprisingly, the lack of information is more acute in developing regions, and Latin America and the Caribbean is no exception.

Private infrastructure financing takes one of two forms: investors may choose to invest directly in infrastructure projects by committing equity or, by lending to specific projects or infrastructure companies (through bonds, loans, and funding from foreign governments and international financial institutions) (Figure 4.12). Investments can be allocated through listed vehicles (such as publicly traded stocks of infrastructure companies, publicly traded government or corporate bonds, and investments in listed infrastructure funds) or unlisted vehicles (such as equity or debt transactions made through private markets, or investments in unlisted infrastructure funds).

The relative importance of each channel in the infrastructure financing market varies greatly across countries. The preferred investment 
Figure 4.12 Infrastructure Financing Market

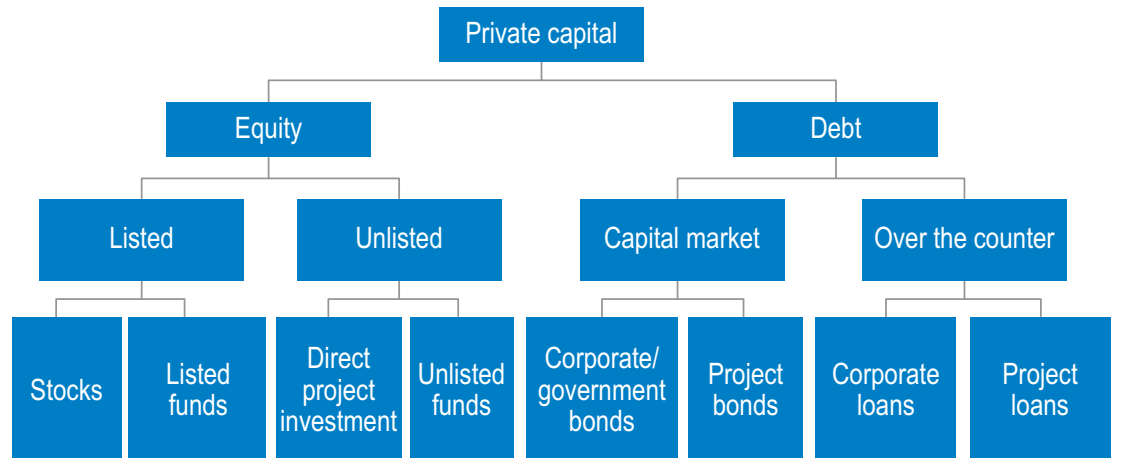

Source: Authors' calculations, adapted from Inderst (2013) and Inderst and Stewart (2014).

vehicles are normally determined by the degree of development of domestic capital markets, the regulatory and governance frameworks, and investors' capacity and knowledge (Estache, Serebrisky, and WrenLewis, 2015). Different agents or instruments generally fund different phases of the project cycle: banks are usually better prepared to assume the risks involved in complex infrastructure operations and to address information asymmetries, particularly in the early stages of the project design, while long-term bond issuances and financing from institutional investors are more viable alternatives to extend and consolidate investment financing later in the project life (Ehlers, 2014; Canuto, 2014). That is why equity and bank loans are more common during the construction phase, when risks are higher, while project bonds are normally used during the operational phases, when projects can generate reliable cash flows and risks are lower.

How is private infrastructure being financed in Latin America and the Caribbean? A natural way to answer this question would be to fill in the boxes in Figure 4.12. However, limitations in data translate into only partial information. No publicly available source details the composition of the Latin American and Caribbean infrastructure finance market. To fill this gap, Serebrisky, Suárez-Alemán, et al., (2015) examined the typology of active investors in the region's infrastructure financing market. ${ }^{20}$ The study relied on a sample of 377 infrastructure projects implemented in Latin America and the Caribbean between 2004 and 2014, obtained from the Infrastructure Journal database, totaling over US\$56 billion. ${ }^{21,22}$ 


\section{Debt Stands Out}

Latin America and the Caribbean's infrastructure has traditionally been financed with lending, as shown in Figure 4.13. Although equity gained ground at the end of the last decade due to the financial crises, debt rapidly recovered thereafter. On average, debt accounted for 67 percent of the private financing for infrastructure between 2004 and 2014. Debt "over the counter"23 (which includes bank loans to infrastructure projects) accounts for almost all debt financing and highlights the lack of depth of capital markets in Latin America and the Caribbean.

Unfortunately, available data are insufficient to disentangle the components of equity financing. The scarce data available suggest that the most common form of equity investment in infrastructure is through unlisted options and mainly by making direct equity contributions to projects. Thus, most of the equity investment in the region is done directly, instead of relying on the stock market or on funds operated by third parties (listed or unlisted).

The composition of financing vehicles and its evolution over time are very similar in Latin America and the Caribbean and worldwide (figures 4.14 and 4.15). Latin America and the Caribbean recovered before, and more quickly, from the financial crises, although the recovery has

Figure 4.13 Evolution of Equity and Debt Shares in Private Infrastructure Financing, 2004-14



Source: Authors' calculations based on Serebrisky, Suárez-Alemán, and others (2015), based on Infrastructure Journal database. 
Figure 4.14 Private Infrastructure Financing by Type of Instrument, 2004-14

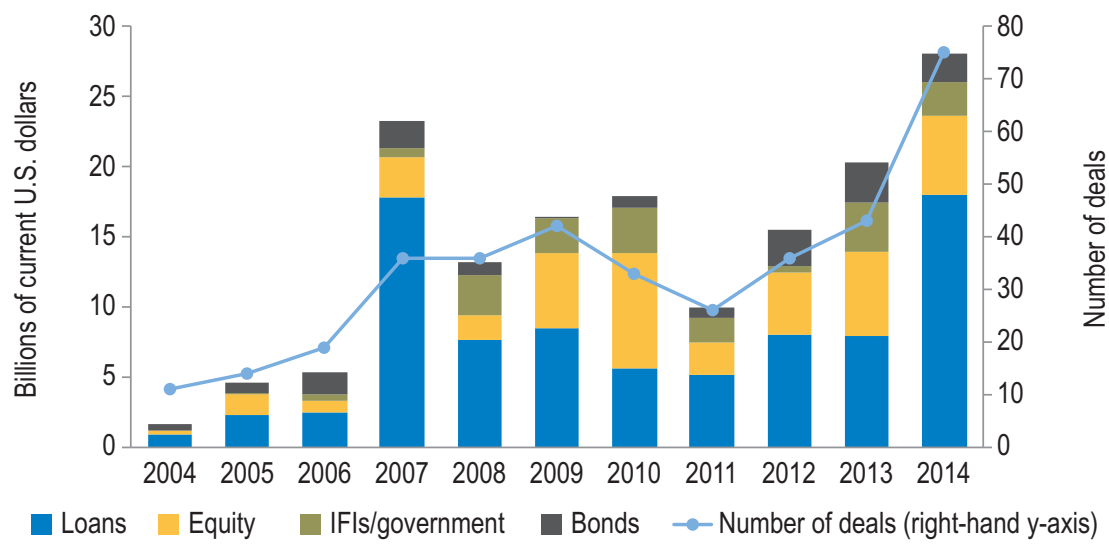

Source: Authors' calculations based on Serebrisky, Suárez-Alemán, and others (2015), based on Infrastructure Journal database.

Note: IFIs = international finance institutions.

Figure 4.15 Worldwide Private Infrastructure Financing by Type of Instrument, 2004-14

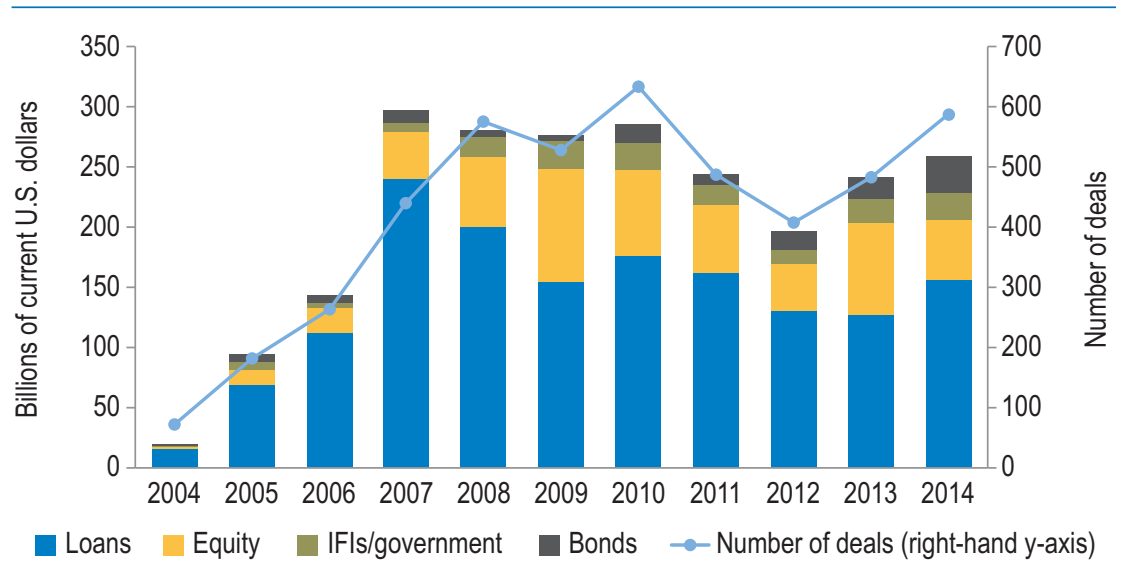

Source: Authors' calculations based on Serebrisky, Suárez-Alemán, and others (2015), based on Infrastructure Journal database.

Note: IFIs = international financial institutions.

been weak; it was not until 2014 that total private financing in Latin America and the Caribbean surpassed its 2007 levels. The shares of debt and equity are similar in Latin America and the Caribbean and worldwide. The remarkable, although expected, fact is that bank loans 
Table 4.1 Private Financing Suppliers in Infrastructure Projects, 2005-14

\begin{tabular}{clc}
\hline Ranking & Type of agent & Share (percent) \\
\hline 1 & Commercial bank & 50.55 \\
2 & National or state bank & 13.65 \\
3 & Developer/eng. procurement or const. firm & 9.12 \\
4 & Private company & 8.83 \\
5 & Multilateral (or) development bank & 7.34 \\
6 & Investment bank & 3.28 \\
7 & Export credit agency & 2.05 \\
8 & Investment or infrastructure fund & 1.90 \\
9 & Government agency/public authority & 1.88 \\
10 & Pension fund & 1.11 \\
11 & Sovereign fund & 0.24 \\
12 & Insurance company & 0.04 \\
\hline
\end{tabular}

Source: Authors' calculations based on Serebrisky, Suárez-Alemán, and others (2015), based on Infrastructure Journal database.

Note: the classification shown is the one used by the Infrastructure Journal database. Eng. Procurement or const. $=$ engineering procurement or construction firm.

have contracted sharply, a direct consequence of more stringent reserve requirements.

Who supplies the financing in this debt-heavy market? Several capital providers participate in the private infrastructure finance market (Table 4.1). Commercial banks hold the largest share of private infrastructure financing in Latin America and the Caribbean, by far: one out of two infrastructure projects were financed by commercial banks during the period studied. ${ }^{24}$ Table 4.1 confirms several interesting facts about private infrastructure financing in the region. First, national development banks play an important role, with a 13.65 percent share. ${ }^{25}$ Second, multilateral development banks' share is low, consistent with previous estimates both for sovereign and nonsovereign lending (Powell, 2013). The participation of institutional investors (such as pension funds, insurance companies, and investment funds) is negligible (less than 2 percent) in the private financing of infrastructure in Latin America and the Caribbean.

\section{Infrastructure as an Asset Class}

In the language of this book, developing infrastructure as an asset class would be a tool to save better, as it provides a mechanism to match private saving with assets that enhance productivity. Infrastructure 
may be thought of as an asset class in its own right, rather than a subclass derived from real estate. Though it resembles real estate, it differs in some fundamental ways. In all cases, infrastructure involves assets with a long lifespan that create recurring, stable returns and are usually indexed by inflation. Compared to real estate, infrastructure is less exposed to economic cycles, has more predictable cash flows (enabling higher leverage), and has legal and sometimes economic barriers to entry (giving stability to returns if economic regulation is adequate). However, as of 2014, not even the most sophisticated investors considered infrastructure an asset class. A recent survey concluded that more than 40 percent of investors still do not categorize infrastructure as an asset in their portfolios (J.P.Mprgan Asset Management and Af2i, 2014).

Despite unmet and fast-growing demand for infrastructure services, the high transaction costs, political and governance risks, and policy and regulatory barriers found in most countries in the region make riskadjusted investment returns too low to attract private investment. The pipeline of well-prepared projects is small; appropriate financial instruments of sufficient liquidity (such as project bonds) to mobilize local investors are lacking; daunting inconsistencies persist in contracts, concessions, bidding documents, and critical underlying cost recovery; and cash flow challenges plague sectors that need private investment. Thus, it is imperative to strengthen institutional capacity in the public sector

along the entire infrastructure project cycle. Better technical capacity in the public sector, coupled with less political interference that alters the economic condition of providing infrastructure services (through arbitrary changes in tariffs and investment programs), would reduce uncertainty and, therefore, the cost of capital faced by private investors. According to a recent study, 87 percent of investors in Latin America and the Caribbean consider institutional weaknesses a major drawback to increase infrastructure investment, compared with 41 percent in Europe and the Middle East, and just 31 percent in Asia and the Pacific (BlackRock, 2015).

\section{Institutional Investors: An Untapped Source of Financing}

Institutional investors, particularly pension funds, insurance companies, and mutual funds, are becoming more important players in financial markets. In the member-countries of the OECD alone, these institutional investors held over US $\$ 70$ trillion in 2012. Most of the attention to attract long-term financing to infrastructure focuses on insurance companies 
and pension funds. In OECD countries, these long-term investors held US $\$ 45$ trillion in assets in 2012 (US $\$ 24$ trillion by insurance companies and US\$21 trillion by pension funds). In Latin America and the Caribbean, the amount was just over US\$1 trillion, or approximately 20 percent of GDP (Della Croce and Yermo, 2013).

Pension funds and their portfolio allocation in infrastructure have attracted much more policy and data-based analysis than insurance companies. Despite the increasing attention, information on the allocation of pension funds to infrastructure is very difficult to obtain, in part because infrastructure is usually not considered an asset class of its own. The OECD is leading an effort to fill the data gap. The first attempt to compare pension fund allocation in infrastructure was by a survey carried out in 2014. Pension funds in Australia and Canada have been the leaders in direct investment in infrastructure, allocating 5 percent of total assets to this sector. ${ }^{26}$

While pension funds in Latin America administer an increasing pool of funds, allocations to infrastructure are low. The countries with the largest portfolios of pension funds under management in the regionmeasured as a percentage of GDP-are Chile (63 percent), Mexico (48 percent), Peru (18 percent), Colombia (16 percent), and Brazil (11 percent). Although the numbers vary according to different sources, the share these funds allocate to infrastructure is relatively minor. Funds in Brazil invest 2 percent in infrastructure; funds in Mexico invest 1 percent; while funds in Chile invest only 0.2 percent (Della Croce and Gatti, 2014). The average allocation to infrastructure of the five countries is 2.6 percent, according to Alonso, Arellano, and Tuesta (2015). Serebrisky, Suárez-Alemán, et al., (2015) calculates a regional average allocation of 1.1 percent between 2005 and 2014.

The current allocation of pension funds in Latin America and the Caribbean-in the range of 1 to 2 percent of total assets under management-is clearly not enough to boost infrastructure investment. But how much exposure to infrastructure would be reasonable for pension funds in Latin America and the Caribbean? Two alternative scenarios are assessed. At the low end is a hypothesis of 3 percent of funds' investment portfolios, which represents the minimum level to contribute in a meaningful way to increase investments in infrastructure. The high-end scenario posits a 7 percent allocation of funds' investment portfolios, which corresponds to the highest exposure to infrastructure by pension funds in the world (observed in Australia and Canada). 
A first stab at estimating the impact on infrastructure investment focuses on stocks of assets under management and calculates the additional total investment in infrastructure that would result from allocating a percentage of the accumulated stock of pension fund assets under management. Suppose pension funds increase their stock exposure to infrastructure by investing 3 percent (or 7 percent) of their assets under management in infrastructure projects. Infrastructure investment would rise significantly in Chile and Mexico. It would also rise-but not enough to have a notable impact-in Brazil, Colombia, and Peru (see Figure 4.16) because of the smaller size of accumulated assets under management in those economies. In Chile, infrastructure investment could rise between 2 percent and 4 percent of GDP (depending on the hypothesis used); this could double the current investment rate. In Mexico, a change of portfolio allocation by pension funds could more than double the current infrastructure investment rate, from less than 2 percent of GDP to nearly 5 percent of GDP. ${ }^{27}$

The preceding exercise uses the stock of assets under management to increase investment in infrastructure. This can be done only once. It is a one-shot deal. Once pension funds reach the hypothesized 3 percent (or 7 percent) exposure to infrastructure, no more funds are available to finance

Figure 4.16 Impact on Infrastructure Investment of a One-Shot Increase in Pension Fund Assets under Management

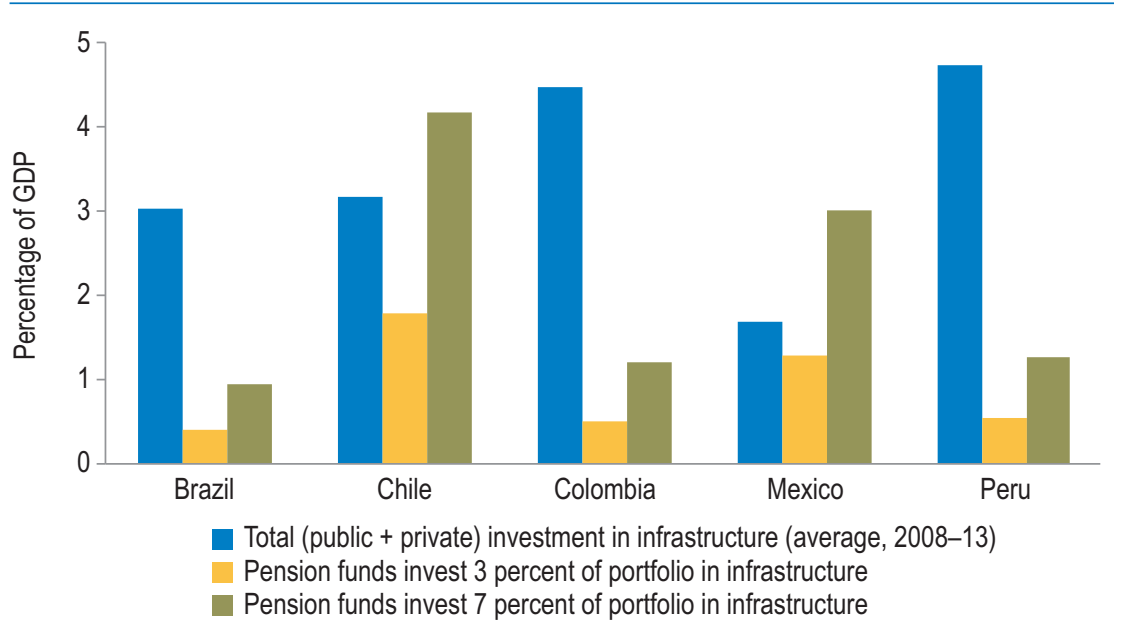

Source: Authors' calculations based on IMF statistics and the following country sources: Superintendência Nacional de Previdência Complementar (Brazil); Superintendencia de Pensiones (Chile); Superintendencia Financiera de Colombia (Colombia); Comisión Nacional del Sistema de Ahorro para el Retiro (Mexico) and Superintendencia de Banca, Seguros y AFP (Peru). 
Figure 4.17 Impact on Infrastructure Investment of Flow Increases in Pension Fund Assets under Management (AUM)

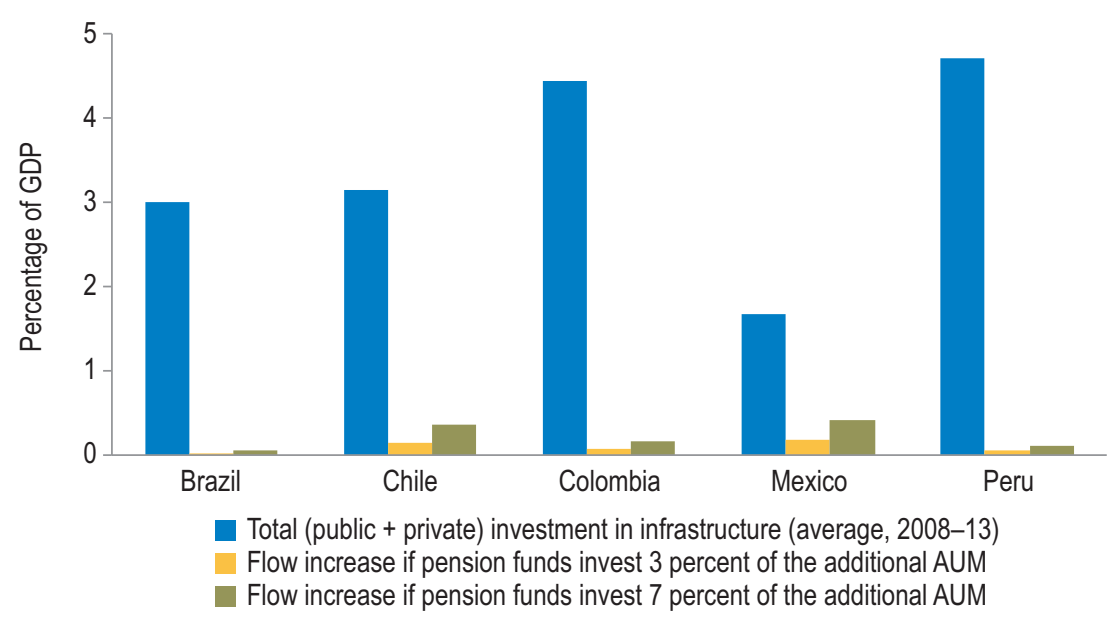

Source: Authors' calculations based on IMF statistics and the following country sources: Superintendência Nacional de Previdência Complementar (Brazil); Superintendencia de Pensiones (Chile); Superintendencia Financiera de Colombia (Colombia); Comision Nacional del Sistema de Ahorro para el Retiro (Mexico); Superintendencia de Banca, Seguros y AFP (Peru).

Note: $A U M=$ assets under management.

additional investments in infrastructure. In order to increase the infrastructure investment rates over time - not just once, but for many years-it is necessary to increase investments using flows, rather than stocks.

What does this mean for pension funds? Pension funds could invest in infrastructure using the additional funds they receive from (net) new contributors to the system and their capital gains. These figures can be obtained by computing the variation in assets under management from one year to the next. Flows, however, are not as big as stocks. Pension fund assets under management tend to grow from year to year (except during years of financial turmoil, like 2008). Between 2007 and 2014, assets under management grew on average around 5 percent of GDP annually in Chile and Mexico, 2 percent in Colombia and Peru, and less than 1 percent in Brazil. Investing 7 percent of these increments in infrastructure generates an annual increase in total investments in infrastructure of 0.35 percent of GDP in Chile and 0.4 percent of GDP in Mexico, the countries where investment would grow the most. In all other countries, pension fund contributions to (annual) increases in total infrastructure investment would not reach 0.2 percent of GDP (see Figure 4.17 and Table 4.2). 
Table 4.2 Potential Additional Investments in Infrastructure Using Flows of Pension Fund Assets under Management (percentage of GDP)

\begin{tabular}{lccc}
\hline & $\begin{array}{c}\text { Total (public + private) } \\
\text { investment (average, }\end{array}$ & \multicolumn{2}{c}{ Additional investment if pension funds invest: } \\
\cline { 3 - 4 } Country & 2008-2013) & $\begin{array}{c}\text { 3 percent of increase } \\
\text { in AUM }\end{array}$ & $\begin{array}{c}\text { 7 percent of increase } \\
\text { in AUM }\end{array}$ \\
\hline Brazil & 3.01 & 0.02 & 0.06 \\
Chile & 3.14 & 0.15 & 0.35 \\
Colombia & 4.45 & 0.07 & 0.16 \\
Mexico & 1.68 & 0.18 & 0.41 \\
Peru & 4.70 & 0.05 & 0.11 \\
\hline
\end{tabular}

Source: Authors' calculations.

Note: $A U M=$ assets under management.

While the additional investment in infrastructure from savings administered by pension funds is sizable in some countries, it's hardly a game changer. Investing 7 percent of the additional assets under management can increase investment in infrastructure by no more than 0.4 percent of GDP in the most optimistic scenario. Table 4.2 shows that infrastructure investment rates increase less than 0.2 percent of GDP in most cases. From this point of view, pension funds may not be the panacea to increase infrastructure investments. The additional investments generated from pension funds would do little to close the prevailing infrastructure gap in Latin America and the Caribbean.

Pension funds may not close the infrastructure gap, but they can still help increase investments in infrastructure. To do so, however, requires an important set of actions beyond the purview of pension funds or their regulators. To begin with, the political risks associated with unstable macroeconomic and regulatory environments must be reduced. Other actions involve reforming regulations that restrict the share of assets under management that pension funds can invest in infrastructure. Removing other barriers will require close collaboration between financial regulators and pension funds in the following areas:

- Asset valuation: Some countries require pension funds to report daily variations in their account balances. Direct investment in infrastructure involves instruments that are not liquid and thus require an ad hoc valuation formula to comply with valuation of the portfolio on a daily basis. 
- Transparency and risks: Because infrastructure assets are seldom transacted in markets, it is difficult for supervisors (superintendents of pension funds) to monitor accurate valuations of the infrastructure asset. Given limited information and resources, it is also difficult for supervisors to assess the performance risks of infrastructure assets.

- Liquidity: Even understanding that infrastructure assets are held over long periods, a superintendent needs to guarantee liquidity of the whole portfolio (this is particularly relevant in countries where constraints for members to change pension funds are low). Thus, there are no incentives to foster the growth of assets, like infrastructure, that are illiquid.

Despite the need to attract private financing to improve Latin America and the Caribbean's infrastructure, the fundamentals of an infrastructure project should not be changed to guarantee investors a rate of return higher than comparable projects. In other words, favorable conditions to attract institutional investors should be created and maintained, but they should not come as excessive costs through higher average prices, or larger subsidies for both operational and capital expenditures.

Pension funds offer the potential to raise private financing in infrastructure. However, they are just one of the building blocks to help finance the construction of the infrastructure needed to support a productive economy. While not negligible, the potential of pension funds is, in fact, limited and highlights the need to tap all available private saving sources (including insurance and other institutional investors) and channel them to infrastructure investment.

\section{Building a Better Investment Strategy}

Investment in Latin America and the Caribbean should increase to levels compatible with high, sustainable, long-run GDP growth rates. Ideally, investment should be close to 25 percent of GDP. Latin America and the Caribbean is far from that level, languishing below 20 percent on average in the last 30 years.

If the region hopes to significantly increase investment, it will have to be financed through national saving. Foreign saving is no match for national saving when it comes to financing domestic investment. Of 
course, greater national saving is a necessary condition to increase investment, but it is not sufficient. In order for the additional saving to have the maximum impact, it must be channeled to the most productive investment alternatives in an efficient manner.

Enter infrastructure. One of the most productive uses for national saving is infrastructure. Efficient, quality investment in infrastructure reduces bottlenecks, which enhances growth prospects. Unfortunately, Latin American and Caribbean countries are not investing enough in infrastructure; in fact, investment as a percent of GDP is lower today than 30 years ago. The infrastructure gap in Latin America and the Caribbean is widening with respect to other developing regions and advanced economies. Local long-term financing-precisely the type provided by national saving-is required to expand the region's infrastructure. Foreign saving is at most a complement to national saving to finance infrastructure.

Lifting infrastructure investment in Latin America and the Caribbean demands an increase in both public and private investment. The public sector will continue to play a very important role because many infrastructure projects have characteristics of public goods. At the same time, the private sector can raise its profile by increasing the efficiency of infrastructure service operations and helping finance infrastructure projects during tight fiscal times, thereby easing the burden on the public sector.

Of course, the private sector is not a monolith. It consists of different agents with different expertise and different attitudes toward risk and uncertainty, who use different vehicles at different stages to invest in infrastructure. The key is to develop infrastructure as an asset class, allowing the expansion of existing vehicles, or the creation of new ones, to attract the most suitable agents at each stage of the project's life cycle. A step in this direction is to attract institutional investors like pension funds and insurance companies that have available resources, and match them to projects that meet their need for long-term returns and low volatility for their investments. This would open up the possibility of increasing the current share of private investment in infrastructure while helping channel future growth of national saving to infrastructure. 


\section{Notes}

1 Countries are classified using the country income classification of the World Bank database. Low-income economies are defined as those with a Gross National Income (GNI) per capita-calculated using the World Bank Atlas method-of US $\$ 1,045$ or less in 2013. Middleincome economies have a GNI per capita of more than US $\$ 1,045$ but less than US $\$ 12,746$. High-income economies have a GNI per capita of US $\$ 12,746$ or more. Lower-middle-income and upper-middle-income economies are separated at a GNI per capita of US\$4,125.

2 The Commission on Growth and Development is a group sponsored by four government organizations from Australia, the Netherlands, Sweden, and the United Kingdom, plus the William and Flora Hewlett Foundation and the World Bank Group. It consists of 19 policy, government, and business leaders, mostly from the developing world, and two Nobel Laureate economists.

3 The countries are Botswana, Brazil, China, Hong Kong, Indonesia, Japan, Rep. of Korea, Malaysia, Malta, Oman, Singapore, Taiwan, and Thailand.

4 The ranking of regions, from the least to the most volatile according to the coefficient of variation, is China (0.18), Advanced Economies (0.21); Emerging Asia (except China) (0.23); Latin America and the Caribbean (0.26); and Sub-Saharan Africa (0.45).

5 Emerging Asia includes China, Hong Kong, India, Indonesia, Republic of Korea, Malaysia, Singapore and Thailand.

6 Nicaragua's foreign saving rate is 15 percent of GDP and Guyana's rate is 10 percent. Other countries have rates close to 8 percent-including the Bahamas ( 7.2 percent), Belize (6.2 percent), and Jamaica (7.4 percent)-but most of these countries have high rates of remittances. The largest economies of the region had foreign saving rates lower than 3 percent of GDP between 1980 and 2014.

7 For a detailed explanation of macroeconomic vulnerabilities caused by excessive reliance on foreign saving, see chapter 5 .

8 Feldstein and Horioka (1980) estimate an econometric model of investment using national saving as a regressor. They find that for every increase of 1 percent of GDP in national saving, domestic investment increases 0.94 percent. 
9 The only possible exception is Sub-Saharan Africa, but even in this region the SFR indicates that most of the domestic stock of capital has been financed with national savings.

10 Attanasio, Picci, and Scorcu (2000) use data for 123 countries from around the world from 1961 to 1994. Serebrisky, Margot, et al., (2015) is based on Attanasio, Picci, and Scorcu (2000), but uses expanded data from 1980 to 2013. The update of Attanasio and his co-authors gains relevance because the time period is associated with increasing financial integration.

11 Bolivia is an interesting case in which investment is lagging behind saving, creating a sizable gap (Jemio and Nina, 2016).

12 The theoretical work on the contribution of infrastructure to productivity and growth began in the 1970s with Arrow and Kurz (1970), which was the first study to include public capital as an input in the economy's aggregate production function. The empirical research started later with Aschauer (1989), and several papers followed. A comprehensive review of the theoretical and empirical literature on the impact of infrastructure on productivity and growth can be found in Infrastructure Canada (2007).

13 This group includes Australia, Canada, Croatia, Iceland, Lichtenstein, New Zealand, Norway, Republic of Korea, Singapore, Switzerland, and Taiwan.

14 Efficiency gains in the provision of infrastructure services have been documented for Latin America and the Caribbean in the last two decades; for details, see Serebrisky (2014). However, these gains have not been able to compensate for the low levels of investment, resulting in the relative deterioration of perception of quality of Latin America and the Caribbean compared to other regions.

15 Data are for Argentina, Brazil, Chile, Colombia, Mexico, and Peru because complete time series for other Latin American and Caribbean countries are available only from the mid-2000s.

16 See, for example, Calderón and Servén (2004) from the World Bank; de Mello and Mulder (2006); Lora (2007); CAF (2009); Carranza, Daude, and Melguizo (2014).

17 See http://app.folha.uol.com.br/\#noticia/563261.

18 See EIU (2014) for a recent study specific to Latin America and the Caribbean that surveyed the enabling environment for public-private partnerships in infrastructure. 
19 See, for example, World Bank (2011); Inderst (2013); Della Croce and Yermo (2013).

20 The sample covers the traditional economic infrastructure sectors: water and sanitation (6.45 percent of total projects): potable water, sanitation services, and flood defenses; power (50.9 percent): generation, transmission, and distribution of electricity (including renewables); transmission and distribution of natural gas; telecommunications (4.7 percent): fixed and mobile telecommunications, satellite and internet connectivity, and multimedia services; transportation (37.9 percent): roads, urban mass transit, rail, ports, airports, and river transport. Social infrastructure or the production of tradable goods like oil and petrochemicals are not covered.

21 The sample is geographically distributed as follows: Brazil (28 percent of projects); Mexico (26.66 percent); Chile (12.92 percent); Peru (7.88 percent); Panama (5.32 percent); Uruguay (3.82 percent); Honduras (2.82 percent); Colombia (2.14 percent); Jamaica (1.86 percent); Costa Rica (1.5 percent); Nicaragua (1.34 percent); Argentina (1.34 percent); and others (4.4 percent, consisting of Bahamas, Dominican Republic, Trinidad and Tobago, Belize, Bolivia, Ecuador, and Guatemala).

22 The World Bank Private Participation in Infrastructure database (PPI) also gathers information for infrastructure projects. It represents the most exhaustive database worldwide in terms of number of projects and investment; it provides information on more than 6,000 infrastructure projects dating from 1984 to 2013. PPI, however, does not break down projects by financing sources. The Infrastructure Journal database is the most comprehensive source that provides this breakdown.

23 The term "over the counter" refers to off-exchange transactions that take place directly between two parties without the supervision of an exchange, such as the New York Stock Exchange.

24 The top commercial banks funding infrastructure in the region are Santander (5.61 percent of total projects amount), Citigroup (3.25 percent), HSBC (3.2 percent), and BBVA (3.14 percent).

25 This share is biased by Brazil, where BNDES, the largest national development bank, accounts for 35 percent of private infrastructure financing in that country.

26 From an investor perspective, pension funds with a separate allocation to infrastructure gain direct exposure to the characteristics of 
the infrastructure asset (including their long-term, stable, and inflation-linked nature). Direct exposure is gained mainly through unlisted equity instruments (direct investment in projects and infrastructure funds) and project bonds, while indirect exposure is normally associated with listed equity and corporate debt.

27 The result is obtained by adding the current infrastructure investment rate of 1.8 percent of GDP and the additional 1.5 percent to 3 percent of GDP that would come from new investments in infrastructure by pension funds. commons.org/licenses/by-nc-nd/3.0/igo/) and may be reproduced with attribution to the Inter-American Development Bank (IDB) and for any non-commercial purpose. No derivative work is allowed.

Any dispute related to the use of the works of the IDB that cannot be settled amicably shall be submitted to arbitration pursuant to the UNCITRAL rules. The use of the IDB's name for any purpose other than for attribution, and the use of IDB's logo shall be subject to a separate written license agreement between the IDB and the user and is not authorized as part of this CC-IGO license. Note that the link provided above includes additional terms and conditions of the license.

The images or other third party material in this chapter are included in the work's Creative Commons license, unless indicated otherwise in the credit line; if such material is not included in the work's Creative Commons license and the respective action is not permitted by statutory regulation, users will need to obtain permission from the license holder to duplicate, adapt or reproduce the material. 